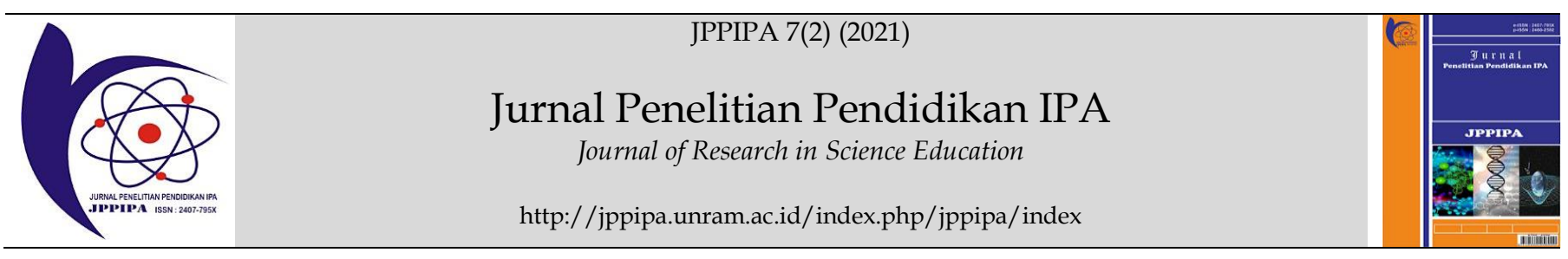

\title{
The Profile of Using Grass Field as a Learning Resource on Ecosystem Materials
}

\author{
Weni Sagala ${ }^{1}$ Ika Chastanti ${ }^{*}$, Dahrul Aman Harahap ${ }^{1}$ \\ ${ }^{1}$ Biology Education, Faculty of Teacher Training, University of Labuhanbatu, Rantauprapat, Indonesia \\ DOI: $10.29303 /$ jppipa.v7i2.584
}

\section{Article Info}

Received: January $16^{\text {th }}, 2021$

Revised: March 31th, 2021

Accepted: April 1th, 2021

\begin{abstract}
The use of grass fields around the school is one way of learning that is carried out outside the classroom and requires students to be able to reason and understand the material so that high student concentration is needed. The research objective was to determine the use of grass fields as a learning resource on the material for ecosystem components. This study used a descriptive method using a qualitative approach, the data analysis technique was carried out in a descriptive qualitative manner using the Miles damn Huberman model. The results showed that the utilization of grass fields as a learning resource on the material for ecosystem components in Senior High School 1 Silangkitang based on (1) Biology is fun (67.70\%); (2) facilities and infrastructure (83.80\%); (3) Net Field 61.20\%; (4) Utilized Field (74.10\%); (5) Following (38.70\%); (6) Interested $(83.80 \%)$; (7) Ecosystem Material (41.90\%); (8) Learning Outcomes (58\%); (9) Finding Facts (41\%); (10) Presenting Data $(35.40 \%)$.
\end{abstract}

Keywords: Profile; Grass field; Learning Resources; Ecosystem

Citation: Sagala, W., Chastanti, I., \& Harahap, D. (2021). The Profile of Using Grass Field as a Learning Resource on Ecosystem Materials. Jurnal Penelitian Pendidikan IPA, 7(2), 143-148. doi:https://doi.org/10.29303/jppipa.v7i2.584

\section{Introduction}

The existence of the surrounding environment gives all the infinite abundance to the living things around it. An environment is a spatial unit with all objects and conditions of living things including humans and their behavior and other living things. The environment around the school is one of the learning media that can be optimized to achieve quality education. The number of learning media available in this environment is not limited, although in general it is not designed deliberately for educational purposes. (Marzuki, 2017).

The use of grass fields as a learning resource can be carried out to develop students' potential, carry out activities outside the classroom, find the causes of an incident and find a relationship between facts in the surrounding environment such as river pollution with the lifestyle of the community and implementation of regulations or legal compliance (Ikhsan et al., 2017).
The use of the environment as a learning resource directs students to actual events and circumstances, natural conditions so that they are more real, more actual and the truth is more accountable, the real benefits that can be obtained by using the environment include making various things that can be learned by students, enabling them to occur a more meaningful learning process, enabling the process of forming students' personalities, learning activities will be more interesting and fostering student learning activities. The type of environment that can be used to optimize learning activities in the classroom consists of the physical environment and the social environment. The physical environment is everything natural and relatively sedentary in nature, such as water, soil, rockrelief, plants, animals, rivers, climate, air temperature. The social environment is concerned with children's interactions in social life and can be used to study social and human sciences (Suhirman, 2018). 
Several factors are driving the increase in the achievements of teachers, among which are initial expertise (Konig et al., 2016). In every ecosystem, there are biotic and abiotic components that interact with each other, as well as in coastal ecosystems. Biotic components are part of the ecosystem which consists of all levels of creatures in the ecosystem, such as plants, animals, fungi, and bacteria. Meanwhile, the abiotic component is part of the ecosystem consisting of physical and chemical (non-living) elements. Physical and chemical elements will form the environment (Yudasmara, 2015).

The environment around the school is one of the learning resources that can be optimized for the achievement of quality educational processes and outcomes for students. Learning resources found in the environment around the school consist of fields that usually have animals and plants, ponds, schoolyards, or gardens with various plants that can be used as objects of observation related to the material knowing the characteristics of living things (Muzria, et al, 2017).

The learning environment can be defined as conditions, influences, and external stimuli which include physical, social, and intellectual influences that affect students (Harjali, et al., 2016). Learning resources are essentially a component of an instructional system which includes messages, people, materials, techniques, and the environment, which can affect student learning outcomes. Thus learning resources can be understood as all kinds of learning resources that exist outside the person (students) and can facilitate the learning process (Nur., 2012).

\section{Method}

In this research approach, the writer uses a qualitative descriptive research method. This research was conducted at Senior High School 1 Silangkitang, South Labuhanbatu Regency. The sampling technique used was purposive sampling. The samples of this research were students of class $X$ and biology teachers of Senior High School 1 Silangkitang. Data collection techniques include in-depth interviews (In-depth Interview) and filling out questionnaire sheets. The collected data were analyzed using qualitative descriptive statistical techniques. The data analysis technique uses the Miles and Huberman model which includes 3 stages: (1) Data reduction, namely (a) summarizing data on direct contact with people, events, and situations at the research site, (b) coding, (c) making objective notes, (d) ) making reflective notes, (e) making marginal notes, (f) storing data, (g) creating memos, (h) analyzing between locations, and (i) creating temporary summaries between locations. (2) Display Data by compiling narrative text. (3)
Verification, namely the conclusion drawing stage (Chastanti, et.al., 2019)

\section{Result and Discussion}

\section{Description of the Utilization of Grass Field as A Learning Source in Ecosystem Component Materials}

The use of grass fields as a learning resource on the material for ecosystem components in Senior High School 1 Silangkitang is based on (1) Fun Biology $(67.70 \%)$; (2) Facilities and Infrastructure $(83.80 \%)$; (3) Net Field (61.20\%); (4) Utilized Field (74.10\%); (5) Following (38.70\%); (6) Interested (83.80\%); (7) Material Ecosystem (41.90\%); (8) Learning Outcomes (58\%); (9) Finding Facts (41\%); (10) Presenting Data (35.40\%). The results showed that the use of grass fields as a learning resource on the material for ecosystem components was not good.

\section{Analysis of Grass Field Utilization for Students as Learning Resources in Ecosystem Component Materials.}

Biology subjects are often considered difficult because learning biology is not only learning in class but learning in the surrounding environment and making observations both in the natural environment and in the laboratory. Biology learning involves a lot of nature as a source of knowledge to be observed. In addition, students are required to be able to understand scientific/Latin names that exist in learning biology which is considered difficult by students. Sometimes students feel lazy to read because it contains words that are difficult to understand, they don't remember the learning they have learned so that it affects the learning outcomes they want to achieve (Made S, et al., 2018). The results of interviews with students indicated that students complained about the learning method applied to the ecosystem component material because it was difficult to understand so that students were not interested in learning it. Abraham et al., (2013) have mentioned that the success of student practical work depends on the ability of teachers to design the activity and to organize the objectives. Teachers must, therefore, be able to develop effective experiments to provide a better practical lesson in biology teaching.

The use of the natural environment as a learning resource can be done in order to develop the potential of students to carry out activities outside the classroom to find the causes of an event in their surroundings and to find out the relationship between the facts in their physical environment (Ikhsan et al., 2017). The environment can be an approach in the learning process, because the environment has many learning resources that can be used as examples in learning, especially in science learning which is closely related to 
nature. Learning resources using the environment provide a good increase in student achievement. Prastowo and Pras (2014) research found that students who take advantage of natural learning resources become closer and more aware of natural situations and can improve student achievement, especially in science learning. Students whose learning resources take advantage of nature can observe, see, and interact directly with natural objects.

The environment has meaning for the continuity of life. Human life and the environment cannot be separated, both the natural environment and the surrounding environment in the form of ecosystems in the environment, both biotic and abiotic. If you are in a school environment, the biotic environment is in the form of friends, fathers and teachers, employees, and animals and plants. The abiotic environment in the school environment is air, tables, chairs, blackboards, and various inanimate objects around (Fahrudin, 2016). Media and learning resources that are close to students are the school environment. The use of the environment as a learning resource as well as an effort to preserve the school environment, namely conducting discussions or case studies on maintaining the school environment and the like, implementing cleanliness and preservation of the school environment (Pantiwati., 2015).

The results of interviews obtained from students showed that the use of grass fields as a learning resource experienced by students at Senior High School 1 Silangkitang made students more enthusiastic about getting to know the ecosystem, both biotic and abiotic. Students also seek information from other learning sources, namely by observing plants outside the school or home environment, using the internet, books, laboratories, and YouTube. The use of the surrounding environment as a learning resource facilitates students to connect their experiences with new information. Learning in the environment is not only focused on the teacher's explanation, but also on interactions with learning objects to achieve learning goals. The result is that students' thinking skills will improve and can avoid misconceptions in learning. All of this is inseparable from positive student interest in learning during the learning process so that it has a positive impact on cognitive learning outcomes (Irwandi, 2019).

Learning using the environment has several advantages, including: a) Students are brought directly into a concrete world about planting learning concepts so that students are not only able to imagine the material; b) The environment can be used any time, anytime, and anywhere so that it is available at any time, but it depends on the type of material being taught; c) The concept of learning using the environment does not cost money because everything has been provided by the natural environment; d) It is easy for students to digest because students are presented with material that is concrete, not abstract (Ifrianti, 2016). Research that applies the environment as a learning resource has been conducted by Sartika (2018) which shows that the use of the environment can improve student learning outcomes.

\section{Analysis of Grass Field Utilization for Teachers as Learning Resources in Ecosystem Component Materials.}

Teachers must have ideas that must be realized for the benefit of students in developing science (Wicaksono, 2017). The results of the interview with the teacher are expected to describe the use of the grass field when learning. The teacher said that they did not often do learning in the school environment, because the use of the school environment was dependent on the material and subject of biology, so the learning material concerned the surrounding environment such as ecosystems and biodiversity. Then the teacher will use the surrounding environment as a learning resource. During online learning, on ecosystem material, the teacher asks students to see and observe the ecosystem around the student's house.

This is also inseparable from the role of creative and innovative teachers in utilizing the surrounding environment as an appropriate learning resource for students. The teacher has a very important role in helping students acquire knowledge. Therefore, teachers should provide learning resources that are more meaningful and easily understood by students (Haryati, 2016).

Biology is a subject that can improve knowledge, skills, and attitudes. Biology is concerned with understanding and finding out about nature systematically for the collection of facts, concepts, and principles which will later become a process of discovery/research. Basically, biology learning seeks to equip students with the knowledge and ability to understand the natural surroundings (Boediono, 2001). Evidence in science can only be proven by conducting practical work or science experiments studies (Crime, 2012). Efforts to use the surrounding environment as a source of student learning must be made optimally. Because basically, the environment provides a variety of useful learning experiences for students. Learning in a way that integrates with the environment will provide real experiences for students. They not only learn theory but observe and feel it directly. The environment as a learning resource is very influential on the physical development, social skills, and culture, emotional and intellectual development of students. Thus three aspects of learning aspects can be 
developed, namely cognitive, affective, and psychomotor (Choiri, 2017).

The school environment is the second main educational environment after the family. Students, teacher administrators, counselors live together and carry out education in an orderly and well-planned manner. The school environment is a continuation of education in the family. School is a bridge for students to mature, interact well in the family environment, and be able to adjust to society. What is learned in school, students are expected to be able to apply it well (Martina, 2019). Learning methods outside the classroom that involve students will show persistence, enthusiasm, enthusiasm, and full participation between fellow students and teachers. The pattern of teacher interaction with students in learning activities is according to the teacher's skills in managing these activities. The application of learning methods outside the classroom (outdoor study) in learning, namely by the way students carry out learning activities outside the classroom or school environment, nature or community. In the learning process outside the classroom, the teacher must pay close attention to how to behave when teaching students outside the classroom because attitudes and behavior in teaching and learning activities outside the classroom will greatly determine the success of students in learning.

Broadly speaking, when a teacher teaches students outside the classroom he is not only a teacher, but as a facilitator, fellow trainer, and motivator (Suherdiyanto, 2014). Teachers do not just deliver material orally without an application but optimize students' abilities in solving a problem. Thus the teaching-learning process is not verbalism but realism (Rohim, 2018). Awang et al. (2013) also found teachers are also incompetent in handling laboratory equipment and have not been able to perform a systematic and efficient experiment. It may be due to the fact that they do not plan and arranged the lesson effectively (Mahanani et al., 2020).

Educational facilities and infrastructure are tools that can help the success of education. For this reason, its utilization and management, and maintenance must be further improved for the better (Rika, 2014). The objectives of the administration of facilities and infrastructure are: 1) Realizing a situation and condition of the school both as a learning environment and as a study group, which allows students to develop their abilities as much as possible. 2) Eliminating various obstacles that can hinder the realization of interaction in learning. 3) Provide and organize learning facilities and furniture that support and enable students to learn in accordance with the social, emotional, and intellectual environment of students in the learning process. 4) Fostering and guiding students according to their social, economic, cultural, and individual characteristics (Uswah, et al., 2019)

\section{Conclusion}

The use of the school environment is carried out so that students are given the widest possible opportunity to actively seek information about everything around them and then use it with learning at school. Learning that is not boring and students learn directly from the real world, not only learning theories from books. Constraints that arise in trying to take advantage of the school environment as learning resources, students' lack of attention when the teacher explains learning. The scope of the environment as a learning resource is wider so that children do not focus on following the learning and their assignments. The effort made by the teacher to overcome this problem is the use of the school environment students are expected to find as much material as possible from the school environment. Teachers make more use of the environment as a learning resource and have to make preparations in the learning process, teachers must play a more role in the classroom environment so that students do not make noise. The environment influences a student's learning process because the environment that is deliberately used as a tool in the educational process can provide experiences to students.

\section{Acknowledgments}

Thank God, Lord of the word, and don't forget the blessing of my parents. To my supervisor, who always helps me to solve it, and friends who have cheered me on.

\section{Reference}

Abrahams, I., Reiss, M. J., \& Sharpe, R. M. (2014). Erratum to The assessment of practical work in school science (Studies in Science Education. Studies in Science Education, 50(1), 143. https://doi.org/10.1080/1743727X.2013.874249

Uswah, U., Evicasari, E., \& Sugiarti, T. (2019). the Effect of Quality Services and Facilities on Student Satisfaction. JKP | Jurnal Kepemimpinan Pendidikan, 2(2), 248-257. https://doi.org/10.22236/ikpuhamka.v2i2.4851

Awang, M. M., Jindal-Snape, D., \& Barber, T. (2013). A documentary analysis of the Government's circulars on positive behavior enhancement strategies. Asian Social Science, 9(5), 203-208. https://doi.org/10.5539/ass.v9n5p203 
Boediono. (2001). Biology Learning Strategies. Yogyakarta: BPFE.

Cimer, A. (2012). What makes biology learning difficult and effective: Students' views. Educational Research and Reviews, 7(3), 61-71.

Chastanti, I., Maharani, G., Sari, N.F. (2019). Analysis of the Use of the Internet on Friendly/Communicative Character in Biology Learning. Pelita Pendidikan Journal, 7(4), 178 - 184. doi: https:// doi.org/10.24114/jpp.v7i4.15421

Choiri, M. (2017). Utilization of the Surrounding Environment as a Learning Source for Children. Journal of Educational Reflection, 8(1).

Fahrudin. (2016). The Effect of Improving Integrated Science Learning Outcomes through the Use of the School Environment as Learning Media for Class VII Students of SMP 13 Kota Bima: Oryza Journal of Biology Education, 2(1).

Nur, F. M. (2012). Utilization of Learning Resources in Class V Elementary School Science Learning on the Subject of Living Things and Life Processes. Jurnal Penelitian Pendidikan, 13(1), 67-78.

Harjali, Degeng, I. N. S., Setyosari, P., \& Dwiyogo, W. D. (2016). Teacher's Strategy in Building a Conducive Learning Environment: A Phenomenology Study in Junior High School Classes in Ponorogo. Jurnal Pendidikan Dan Pembelajaran, 23(1), 10-19

Haryati, Dini. (2016). The Effectiveness of the Use of the School Environment as a Learning Source on the Science Learning Outcomes of Class IV Students of SD Inpres Btn Ikip I Makassar: Journal of Islamic Basic Education, 3(2). 80-96

Ifrianti, S. (2016). Utilization of the Surrounding Environment as Social Studies Learning Media to Increase the Activities and Learning Outcomes of Class III Students of MIN 10 Bandar Lampung. Journal of Education and Basic Learning, 3(2), 237240.

Ikhsan, A., Sulaiman, \& Ruslan. (2017). Utilization of the School Environment as a Source of Learning in SD Negeri 2 Teunom Aceh Jaya. Jurnal Ilmiah Pendidikan Guru Sekolah Dasar, 2(1), 1-11. https://www.neliti.com/id/publications/18766 $1 /$ pemanfaatan-lingkungan-sekolah-sebagaisumber-belajar-di-sd-negeri-2-teunom-aceh.

Irwandi, I., \& Fajeriadi, H. (2020). Utilization of the Environment as a Learning Source to Increase High School Student Interest and Learning Outcomes in Coastal Areas, South Kalimantan. BIO-INOVED: Jurnal Biologi-Inovasi Pendidikan, 1(2),

66. https://doi.org/10.20527/binov.v1i2.7859

Konig, J, Lammerding, S, Nold, G, Strault, S. (2016). Teachers' Professional knowledge for teaching english as a foreign Language: Assessing the Outcomes of Teacher Education. J. Teach. Educ, 7(1), doi:

https://doi.org/10.1177/0022487116644956

Mahanani, C., Wening, S., Susanto, M. R., Sudirman, A. (2020). The effect of laboratory knowledge, teaching practice experience, and work motivation on laboratory management. In Journal of Physics: Conference Series, 1446(1). IOP Publishing

Martina. (2019). The Influence of the School Environment on Student Learning Outcomes in Islamic Religious Education Subjects at SMP Negeri 9 Tulung Selapan: Oki Regency. Raden Fatah's Pai Journal, 1(2)

Marzuki, A. (2017). Utilization of the School Environment as a Biology Learning Media for Understanding the Concept of Ecosystem Materials: Journal of Teacher Training and Education, 1(2)

Muzria, M.L., Mestawaty, As.A., \& Puadi, R.I. (2017). Utilization of the Surrounding Natural Environment as a Learning Source in Improving Science Learning Outcomes of Class III Students of SDN 10 Gadung. Creative Journal Online, 5(3)

Pantiwati, Y. (2015). Utilization of the school environment as a learning resource in a lesson study to improve metacognitive. Bioedukatics journal, 3(1)

Prastowo, W.U.S., \& Pras, P. (2014). The Effect of Utilization of the Environment Around the School on Student Learning Outcomes in the Main Material of Ecosystems: Proceedings of the National Seminar on Biology and Learning.

Rika, M. (2014). Improved Management of Educational Facilities and Infrastructure to Improve the Quality of Learning at SMPN 5 Bukit Tinggi. Journal of Educational Administration, 2(1).

Rohim, A, \& Arezqi, T.A. (2018). The Effectiveness of Learning Outside the Classroom (Outdoor Learning) with the PMRI Approach to the Spldv Material: Electronic Journal of Learning Mathematics, 5(3).

Sartika, Y. (2018). Utilization of the Environment Around the School as a Learning Source in Sub-Chapter Material Classification of Living Things at SMPN 14 Kluet Utara, South Aceh Regency. Essay. Banda Aceh: Ar-Raniry University.

Subrata, M, (2018). Utilization of Grass Field as a Learning Resource on Plantae Material for Class $X$ MIA Students of Senior High School 1 Abiansemal in Academic Year 2015/2016. Jurnal Kesehatan Masyarakat, 7(1).

Suherdiyanto. (2014). Application of Learning Methods outside the Classroom (Out Door Study) in 
Material of Environmental Problems and Efforts to Overcome it in MTS Al-Ikhlas Kuala Mandor Students B. Journal of Social Education, 1(1)

Suhirman. (2018). Management of Learning Resources in Improving Student Understanding. Journal of Early Childhood Islamic Education, 2(1).

Wicaksono, A. (2019). Looking for an Ideal Educational Character for Indonesia (In Stories and Reality from Time to Time). Lantern: Educational Scientific Journal, 1(2).

Yudasmara, G.A, (2015). Analysis of Diversity and Relative Abundance of Microscopic Algae in Various Ecosystems in the Intertidal Area of Menjangan Island: West Bali. Project: Species richness and relative abundance of reef-building corals in the $\underline{\text { Indo-west Pacific }}$ 